\title{
ТЕХНОЛОГІЯ ДІАЛОГІЧНОГО НАВЧАННЯ ЯК СКЛАДНИК ПРОФЕСІЙНОЇ ОСВІТИ МАЙБУТНІХ УЧИТЕЛІВ
}

У статті розглянуто технологію діалогічного навчання студентів у ВНЗ, побудовану на принципі рольової перспективи.

Ключові слова: діалог, технологія діалогічного навчання, рольова перспектива.

В статье рассматривается технология диалогического обучения студентов в вузе, построенная на приничие ролевой перспективы.

Ключевые слова: диалог, технология диалогического обучения, ролевая перспектива.

The article deals with the technology of dialogical training at universities, based on the principle of role prospect.

Key words: dialogue, technology of dialogical training, role prospect.

Успіх формування професійної готовності студентів грунтується на впровадженні технології діалогічного навчання в педагогічний процес. Специфіка технології полягає в проектуванні студентами нового знання, віднесеного до змістового аспекту досліджуваної інформації, 3 урахуванням особистого освітнього досвіду, вираження взаємозалежних за змістом поєднань думок і суджень питально-відповідної форми. Основу технології діалогічного навчання складає цілеспрямована, організована взаємодія суб'єктів педагогічного процесу, що будується на принципах співпраці, співтворчості і співпереживання, передбачає наявність проблеми, що має різні варіанти розв’язання, бажання студентів у процесі взаємного обміну думками дібрати з різних відповідей найбільш оптимальну.

Meта статmі - проаналізувати підходи науковців до проблеми впровадження технології діалогічного навчання в навчальний процес вищих навчальних закладів, показати використання технології, побудованої на принципі рольової перспективи, у практиці роботи у вищій школі.

У процесі навчання, побудованого на принципах педагогічної взаємодії, співробітництва й співтворчості, майбутні вчителі оволодівають прийомами встановлення контакту, ознайомлюються 3 оптимальними комунікативними нормами і зразками діалогу з учнями. Тому використання імітаційно-ігрових форм і методів навчання позитивно впливає на рівень готовності до професійної діяльності майбутніх педагогів. Так, при правильній організації ділової гри студенти оволодівають комунікативними уміннями й розвивають комунікативну культуру, що виступають важливими характеристиками їхньої готовності до діалогу з учнями. Під час програвання рольових ситуацій, що моделюють діалогічне спілкування в системі «вчитель-учень», студенти закріплюють уміння встановлювати контакти одне з одним, а згодом контактувати з цілим класом.

Використання імітаційно-ігрових і проблемно-ситуативних методів створює оптимальні умови, до яких належать емоційна насиченість навчальної діяльності, зв'язок наочно-чуттєвого і абстрактнологічного в процесі засвоєння матеріалу [3, с. 7]. Ігрові методи закріплюють діалогічні уміння, досвід діалогічного спілкування й професійної поведінки в діалогічних ситуаціях (В. Баранов, Н. Баришникова, О. Вербицький, Ф. Ельконін). Ситуації, які обговорюються в ході гри, добираються за їхньою типовістю стосовно сучасної школи. Досвід показав доцільність розроблення ігрових циклів, в основу яких покладено програму формування здібностей, необхідних для педагогічного навчального діалогу.

Відтак моделювання реальної шкільної дійсності дозволяє реалізувати діяльний підхід до розвитку професійних здібностей майбутніх учителів. Поділяючи думки О. Алексюка, О. Бодалєва, О. Вербицького, Ю. Ємельянова, Л. Кондрашової, ми схильні вважати, що активні методи підготовки допомагають забезпечити «природний перехід студентів від одного виду діяльності (пізнавального) до іншого (професійного), із відповідною зміною предмета, мотивів, цілей, засобів і результатів» [1, c. 134].

Традиційна технологія навчального процесу значно знижує пізнавальну активність студентів, рівень їхньої самостійності, ініціативи й творчості під час розв'язання навчальних завдань. Вихід 3 такої ситуації Л. Кондрашова вбачає у використанні технології навчання, побудованого на принципі рольової перспективи, основними характеристиками якої є:

- чіткість визначеної дидактичної мети у формі рольової перспективи;

- структурування навчальної інформації у вигляді імітаційно-ігрової й проблемно-ситуаційної моделі, іï реалізація через програвання різних ролей у комунікативній ситуації, максимально наближеній до реальної педагогічної практики;

- педагогічна взаємодія, співпраця і співтворчість у системі відносин «викладач-студент»;

- опора на творчий потенціал та індивідуальні можливості студентів під час програвання навчальних ролей професійної спрямованості;

- надання студентам свободи вибору навчальних ролей; 
- створення ситуації успіху для кожного з тих, кого навчають, і позитивна оцінка його дій при досягненні рольової перспективи [4, с. 294].

Пропонована у вищій школі технологія навчального процесу передбачає оптимальні умови для формування готовності майбутніх педагогів до діалогічного навчання. Ї̈і особливість полягає в моделюванні навчальних ситуацій, «під якими розуміють процес побудови деякого прообразу явища, що вивчається, об’єкта, що розкриває характер спілкування в системі «учитель-учень», реалізації навчально-ігрових ролей, що забезпечує активний вплив на саморозвиток особистості майбутнього вчителя-професіонала» [4, с. 295]. Беручи участь у різних навчальних ситуаціях (діалог, навчальна дискусія, диспут), студенти оволодівають умінням висловлювати свою думку щодо питання, яке розглядається, виявляють самостійність мислення, відпрацьовують дії й тактику поведінки в діалогічних ситуаціях, виробляють навички професійної поведінки.

Готовність студентів до діалогу культур як засобу спілкування з учнями визначається за тим, як майбутній учитель опанує теорію діалогу, методику й технологію діалогічного навчання, наскільки його особистісні якості будуть відповідати вимогам до діалогічної діяльності й спілкування, як він оволодіє діалогічними уміннями і досягає стійкої настанови й позитивної мотивації щодо використання діалогу в навчальному процесі.

За основу нашого дослідження було взято концепцію М. Данилова про введення діалогу на етапі підготовки тих, кого навчають, до сприйняття навчальної інформації. Цей науковець рекомендував: 1) спеціальне повторення раніше пройденого; 2) коротке розкриття значення матеріалу, що підлягає вивченню, для теорії і практики; 3) виклад плану засвоєння нових знань, визначення основної ідеї, що допоможе усвідомити логіку нового матеріалу; 4) постановка питань, задач, завдань, що спонукають до необхідності пізнати нове; 5) аналіз соціальних проблем, зіткнення тих, кого навчають, 3 тими явищами, які вони не можуть зрозуміти самостійно, але пізнання яких для них потрібне; 6) спостереження, проведення попередніх експериментів [2, с. 118]. Розроблена М. Даниловим логіка процесу навчання $\epsilon$, власне кажучи, діалогічною. Запровадження або застосування цих прийомів на заняттях у вищій школі створює основу для вироблення в студентів уміння використовувати зміст навчального матеріалу як підгрунтя, на якому розкривається діалог.

У дослідно-експериментальній програмі передбачалося два види навчання: аналітичне й синтетичне, які спрямовані на озброєння студентів методикою й технологією навчального діалогу. Завдання полягало в тому, щоб виявити в процесі формувального експерименту ефективність аналітичного (від поелементного складу до загального уміння) і синтетичного (усного засвоєння видів діалогу) шляхів навчання «діалогічної дидактики». Відмінності між цими двома видами навчання подано в таблиці 1.

\begin{tabular}{|l|l|}
\hline \multicolumn{2}{|c|}{ Таблиця 1} \\
\hline Аналітичне навчання & Синтетичне навчання \\
\hline $\begin{array}{l}\text { 1.Теоретична підготовка } \\
\text { навчального діалогу }\end{array}$ & 1.Теоретична підготовка \\
\hline $\begin{array}{l}\text { 3.Вирішення педагогічних завдань } 3 \\
\text { діалогічного навчання }\end{array}$ & - \\
\hline $\begin{array}{l}\text { 4.Практичне проведення навчальних } \\
\text { діалогів в імітаційній групі }\end{array}$ & $\begin{array}{l}\text { 2.Практичне проведення навчальних } \\
\text { діалогів в імітаційній групі }\end{array}$ \\
\hline 5.Проведення уроку-діалогу & 3.Проведення уроку-діалогу \\
\hline
\end{tabular}

Не менш важливим у побудові програми дослідного навчання виявилося структурування змісту особистісно зорієнтованого діалогічного навчання. У змісті дисциплін педагогічного циклу насамперед виокремлюється діалогічний підхід до структурування навчальної інформації, технологізації видів діяльності студентів, спрямованої на вироблення в них діалогічних умінь i професійних якостей, що забезпечують результативність діалогу в навчальному процесі. У зв'язку 3 цим у курсах педагогічної спрямованості було виділено теми, вивчення яких можливе 3 використанням навчального діалогу і введено тренінги, що забезпечують технологічну підготовку майбутніх педагогів до діалогічного навчання.

Під час дослідно-експерементальної роботи студенти одержували основні відомості про діалог, його можливості й функції у навчальному процесі, структуру і вимоги, від дотримання яких залежить його ефективність. Цим знанням передував курс із методики педагогічної взаємодії і спілкування в системі «учитель-учень». Під час занять студентів підводили до висновку про те, що процес спілкування і взаємодії сприяє продуктивності навчання за наявності співпраці вчителя й учнів, зміст якої полягає в появі «двоголосого» чи «поліголосого» слова, тобто діалогу. Із метою оволодіння методикою діалогу майбутні педагоги ознайомлювалися 3 різними його видами. Дослідною програмою передбачалося використання на лекціях і семінарських заняттях зовнішнього діалогу (проблемного діалогу, діалогу-пошуку, діалогу-протиборства тощо). Ми виходили 3 того, що готовність до діалогічного навчання успішно формується у студентів тільки за наявності досвіду активної участі в різних формах зовнішнього діалогу. Під час діалогу-проблеми шляхом спільних логічних міркувань вибудовується алгоритм розв’язання навчальної проблеми. Так, у процесі діалогу-пошуку з безлічі варіантів необхідно обрати найбільш оптимальний спосіб для знаходження істини, провести аналіз декількох шляхів, що ведуть до пізнання істини; діалог-протиборство навчає майбутнього вчителя відстоювати власну думку, власний погляд, позицію, логічно розгортати власні 
аргументи. Ці види діалогу виробляють у студента психологічну стійкість і впевненість у собі, готують його до розв'язання реальних професійних ситуацій.

Технологія дослідного навчання передбачає чотири основні етапи:

- етап обгрунтування, на якому визначалися: а) ціннісні орієнтири; б) цілі діалогічного навчання, яких треба було досягти до кінця реалізації дослідної програми; в) формальні аспекти, що стосуються контексту навчального процесу з використанням діалогу і його змісту; г) конкретні методики, завдання, тренінги, що дозволяють реалізувати поставлені цілі; г) час, місце, контингент студентів; д) методичне забезпечення навчального процесу;

- етап прийняття рішення, на якому було розроблено: а) конкретну програму дослідного навчання; б) навчально-методичне забезпечення діалогічної побудови навчальних занять; в) визначено форми, методи і засоби, що дозволяють здійснити реалізацію програми;

- етап здійснення передбачав: а) конкретну організацію дослідного навчання; б) колектив безпосередніх учасників i виконавців; в) систему стимулювання комунікативно-діалогічного середовища; г) удосконалення, корегування змісту дослідних завдань; г) вибір способів реалізації дослідного матеріалу й інноваційних стратегій навчання; д) створення необхідних умов, що забезпечують результативність дослідного навчання у розв'язанні поставлених завдань;

- етап, коли навчальний процес перестає усвідомлюватися як інноваційний, а стає звичним у дидактичній реальності вищої школи, що має свої цілком визначені функції й статус.

Контекст використання різних видів діалогу на дослідних заняттях очевидний для викладача, але прихований для студентів: їх не тільки залучали до пізнавальної ситуації, спонукали до аналізу, визначення об'єкта аналізу, але й спрямовували на предмет досліджуваної теми. У цьому випадку діалог використовувався як дидактичний засіб із метою усвідомлення предмета вивчення і сутності навчальної проблеми, винесеної на обговорення.

Отже, упровадження технології діалогічного навчання дозволяе сформувати в майбутніх педагогів настанову на діалог як засіб творчого розвитку особистості, раціональну пізнавальну діяльність, яка стимулює інтелектуальний, моральний, духовний потенціал майбутнього фахівця.

\section{Література}

1. Вербицкий А. А. Игровые формы контекстного обучения / А. А. Вербицкий. - М. : Знание, 1983. - 95 с. 2. Данилов М. А. Процесс обучения в советской школе / М. А. Данилов. - М. : Политиздат, 1960. - 200 с. 3. Зимняя И. А. Личностно-деятельностный подход к обучению иностранному языку взрослых в интенсивном курсе / И. А. Зимняя // Труды МГПИЯ им. М. Тореза. - М., 1988. - Вып. 280. - С. 4-15. 4. Кондрашова Л. В. Организация учебного процесса в высшей школе на принципах ролевой перспективы / Лидия Валентиновна Кондрашова // Технологии непрерывного образования и творческого саморазвития личности. - Гродно : ГГУ, 1999. - C. 293-297. 